\title{
OUTSOURCING - RIZIČNA UŠTEDA?
}

\section{Dina Liović}

Sveučilište Josipa Jurja Strossmayera u Osijeku,

Ekonomski fakultet u Osijeku, Osijek, Republika Hrvatska

\begin{abstract}
Apstrakt:
S ciljem ostvarenja optimizacije svih čimbenika poslovanja, poduzećima se kao jedan od modela upravljanja nudi outsourcing, model koji počiva na ideji potpune posvećenosti poduzeća njegovoj primarnoj djelatnosti, uz prepuštanje svega ostalog za to specijaliziranim tvrtkama. S tog aspekta, outsourcing predstavlja učinkoviti model upravljanja, no njegova primjena otvara pitanja ima li i koji su pak tome nedostaci i koliko je ono rizično? S obzirom da su za outsourcing podobni apsolutno svi segmenti i odjeli poslovanja, ključno je i pitanje njegovog utjecaja na zaposlenike i hoće li ono dugoročno biti isplativo i učinkovito? Uz izloženost stalnim pritiscima za poboljšanjem poslovnih rezultata, odjeli financija i računovodstva u svakom su poduzeću, bez obzira na veličinu i djelatnost, obvezni baviti se računovodstvom, porezima te povezanim poslovima. Detaljan pregled i analiza prednosti, nedostataka, kao i posljedica primjene outsourcinga - $s$ aspekta sve razvijenijeg outsourcinga financija i računovodstva provest će se komparativnom i deskriptivnom metodom. S obzirom na pozitivna iskustva i razvijenost outsourcinga, neupitne su brojne prednosti primjene istog, no ono što je ključno i što se postavlja kao temeljni cilj i svrha radu jest istražiti i utvrditi nauštrb čega se one ostvaruju te koliko rizična primjena outsourcinga može biti za poduzeće i sve njegove dionike.
\end{abstract}

Ključne reči:

zahtjevi i konkurentnost tržišta, efikasnost, smanjenje troškova, poboljšanje poslovanja, rizik.

\section{UVOD}

Pitanje outsourcinga sve je aktualnije - kako u privatnom, tako i javnom sektoru; kako u svijetu, tako i u Republici Hrvatskoj ( $u$ nastavku $R H$ ), gdje se o outsourcingu učestalo raspravlja unazad nekoliko godina, i bez obzira što on suštinski treba donositi boljitak poduzeću i predstavlja dobru strategiju poslovanja za poduzeće, još uvijek nije na taj način percipiran i dalje se smatra kontroverznim. Brojni su razlozi navedenom, ali strah i zaziranje od nečeg novog, od promjene, kao i nedovoljna upućenost i saznanja o samom outsourcingu, te strah od gubitka stalnog radnog mjesta mogu se istaknuti kao oni ključni. Gledano s aspekta uprave poduzeća, kao ključan razlog sprječavanja angažmana poduzeća za outsourcing, navodi se slab izbor poduzeća koji nude željenu uslugu. Prethodno ukazuje na nisku razinu znanja što se i koliko kvalitetno nudi na tržištu RH u području outsourcinga. Također, sam naziv outsourcing, s obzirom da je stranog podrijetla, velikom dijelu javnosti predstavlja i veliku nepoznanicu. Stoga, kako bi se pojam outsourcing približio hrvatskom stanovništu, engleski izraz prevodi se kao izdvajanje ili pak eksternalizacija posla, odnosno poslovnih procesa. Bez obzira jesu li navedeni pojmovi prikladniji i razumljiviji, svakako sami po sebi ne govore sve što sam outsourcing predstavlja - izdvajanje (eksternalizaciju) sporednog posla (non core business) vanjskim poduzećima koja se istima bave, a sve s glavnim ciljem - poboljšanjem produktivnosti i efikasnosti primarne djelatnosti poduzeća (core business), uz istovremeno smanjenje troškova poslovanja. Outsourcing je sve rasprostranjenija strategija poslovanja, za koju se smatra i očekuje da će u RH kroz dogledno vrijeme zaživjeti u punom svom smislu, a kroz desetak godina postati i pravilo, a ne iznimka. Glavni razlozi i motivi pisanja 
rada ove tematike jest činjenica kako je, pregledom dostupne literature i provedenih istraživanja, područje outsourcinga računovodstvene djelatnosti u RH još uvijek nedovoljno istraženo i nepoznato područje. Također, postojanje istraživanja, kao i dugogodišnja praksa primjene outsourcinga u primjerice području outsourcinga informacijskih tehnologija (u nastavku IT outsourcing) upućuje na mogućnost i potrebu provedbe istraživanja i u drugim djelatnostima te utvrđivanja razloga još uvijek nedovoljne primjene istog.

Problematika rada biti će obrađena kroz četiri tematska poglavlja, gdje se u prvom stavlja naglasak na sam pojam outsourcinga te definiciju istog, nakon čega slijedi detaljnija obrada područja outsourcinga računovodstvene djelatnosti. Nakon teorijskog osvrta, navode se razlozi za i protiv outsourcinga, odnosno prednosti i nedostaci primjene istog. Sljedeće tematsko poglavlje prikazuje rezultate provedenih istraživanja te osvrt na trenutnu situaciju i iskustva primjene outsourcinga u RH. Posljednjim, zaključnim poglavljem sumiraju se sve navedene činjenice, iznose zaključci, kao i prijedlozi te preporuke za provedbu daljnjih istraživanja.

\section{OUTSOURCING - TEORIJSKI OSVRT}

Outsourcing nije novi koncept, već je pod različitim terminima prisutan još od rane povijesti. Za outsourcing se može reći kako zapravo postoji od postanka same trgovine. U 14. stoljeću, trgovci iz cijele Europe iznajmljuju skladišta u Veneciji, a davne 1476. godine, redovnici iz San Iacopo di Ripoli-a, prilikom obavljanja svoje tiskarske djelatnosti koriste usluge nekoliko različitih pisača, odnosno tiskarskih strojeva (Anadachee, 2012). Premda tada nepoznato, svaki od navedenih primjera pravi je primjer outsourcinga i odgovara definiciji istog. Jer, u svojoj suštini, outsourcing označava upravo to prijenos rada (posla) vanjskom izvođaču. Može se definirati i kao strateško korištenje vanjskih resursa za obavljanje djelatnosti tradicionalno izvršavane od strane internog osoblja i internih resursa, ili kao ugovorno prenošenje posla na vanjskog dobavljača (proizvođača) za uslugu ili aktivnost koja se obično, ali ne uvijek, izvodi unutar poduzeća. Ključno kod outsourcing-a jest mogućnost koncentriranja poduzeća na njegove osnovne kompetencije, prenošenjem nekih od poslova kooperantima (Anadachee, 2012).

Iako je outsourcing sve aktualniji, posebno popularan i medijski popraćen u posljednjih nekoliko godina, za njega se ne može reći kako je moderan koncept, već strategija koja se prakticira već tisućljećima. Povijesno gledano, najviše zabilježenih slučajeva outsourcinga vezano je uz prikupljanje poreza. Osmansko i Rimsko carstvo prikupljanje poreza outsourcingom povjeravali su privatnim osobama kroz niz ugovora kao što su aukcije ili ugovori o fiksnim cijenama, bazirano na broju poreznih obveznika nekog kraja. Privatnoj agenciji za prikupljanje poreza bilo je dopušteno zadržati bilo koji prihod prikupljen iznad dogovorenog iznosa. Često su ovi ugovori za prikupljanje poreza dodijeljivani vojnim skupinama i drugima, koji su bili dovoljno zastrašujući i kreativni da prikupe dovoljno novca od stanovništva kako bi zadovoljili dogovoreni iznos, a sebi ostavili dovoljnu dobit za poprilično lagodan vlastiti život. Primjena outsourcinga, u sadašnjem obliku kao jedne od poslovnih strategija, započela je za vrijeme Drugog svjetskog rata. Tijekom tog razdoblja, američka vlada koristi alate za kvantitativnu analizu i inženjering kako bi poboljšala učinkovitost svoje proizvodnje i distribucije vojnih potrepština i zaliha (Espiritu, 2008).

Outsourcing često podsjeća na vanjsko ugovaranje i druge poslovne odnose s partnerskim poduzećima, primjerice dobavljačima, no detaljnija definicija govori kako se outsourcingom određeni poslovni procesi prepuštaju specijaliziranim partnerskim poduzećima koja imaju mogućnost te poslovne procese obavljati kvalitetnije i jeftinije, uz zadržavanje komunikacije s poduzećem s kojim su potpisali ugovor o outsourcingu. Na taj se način poduzeće koje je odlučilo izdvojiti određene poslovne procese može usmjeriti na ključne poslovne procese (Latinović, 2010). Bahtijarević-Šiber i Sikavica (2001) navode kako je outsourcing (eksternalizacija) zapravo orijentacija poduzeća na napuštanje aktivnosti u kojima je konkurencija bolja, a s kojom je poduzeće obično povezano u mrežu. Zatim, poduzeća se orijentiraju na svoj glavni posao, a ostale poslove, u kojim su slabiji od konkurencije, eksternaliziraju. Paliaga (2007) definira outsourcing kao ugovaranje ili prepuštanje dijelova poslova ili cijelih poslova privatnim poduzećima, na način da preuzmu odgovornost i posao državne ili lokalne uprave u određenom djelokrugu, funkciji ili procesu za što administracija ostaje odgovorna, ali isti više izravno ne obavlja.

Ključno pitanje koje se postavlja jest na koji način odrediti za koji bi posao outsourcing bio prikladan, a za koji pak ne? Svakoj ozbiljnijoj raspravi o outsourcingu, mora prethoditi razlučivanje poslova koji se mogu uključiti u outsourcing i poslova koji ne mogu. Načelno, poslovi se u bilo kojoj organizaciji mogu podijeliti na procesne i projektne. Obilježja procesnih poslova su njihovo ponavljanje, obavljanje u kraćem vremenskom razdoblju, standardizacija, da nisu kreativni, da su dokumentirani i da ne odstupaju i ne mijenjaju se promjenom ljudi koji ih obavljaju. Za razliku od njih, projektni poslovi su jedinstveni, obavljaju se i događaju u dužem vremenskom razdoblju, njihova dokumentiranost je otežana, kao i standardizacija jer se ne ponavljaju uvijek u istom obliku, a posebno ovise o osobama koje ih obavljaju i o njihovoj kreativnosti. Procesni poslovi u načelu čine od $70 \%$ do $80 \%$ svih poslova bilo kojeg poduzeća, dok ostatak čine projektni poslovi. S te osnove, može se zaključiti kako se izvršenje procesnih poslova, bez gubitka na kvaliteti i uz ostvarenje napretka u efikasnosti, može prepustiti drugima (Paliaga, 2004). Kao i kod podjele poslova, i donošenja odluke koji se poslovi mogu prepustiti outsourcingu, bitno je i razlikovati vrste outsourcinga te koji od istih je najprikladnije primjenjivati u određenom poduzeću. Kada se govori o vrstama outsourcinga, postoje tri 
vrste istog: strateški, taktički (parcijalni) i ciljani outsourcing. Pod strateškim outsourcingom smatra se prepuštanje cijelih procesnih funkcija u potpunosti tržištu, uz zadržavanje nadzora i kontrole. Taktički ili parcijalni outsourcing označava prepuštanje tržištu samo jednog dijela procesa, primjerice kod procesa bi prodaje to bila komunikacija s kupcima i rješavanje pritužbi. Kod posljednje vrste - ciljanog outsourcinga, najčešće korištene vrste, na tržištu se kod projektnog posla unajmljuju stručnjaci ili specijalizirane tvrtke koje moraju odraditi određeni dio posla. Strateški i taktički outsourcing usmjeren je na procesne poslove, a ciljani je u biti sastavni dio projektnog outsourcinga (Drljača, 2010).

\section{OUTSOURCING RAČUNOVODSTVENE DJELATNOSTI}

Outsourcing računovodstvene djelatnosti, kao i sve druge vrste outsourcinga, razvija se velikom brzinom u posljednjih desetak godina, zahvaljujući liberalizaciji trgovine, razvoju komunikacijske tehnologije i konstantnom tehnološkom rastu i razvoju. Samo neke od računovodstvenih usluga koje se izdvajaju (eksternaliziraju) u poduzeću su: priprema poslovnih i osobnih poreznih prijava, knjigovodstvene usluge, uključujući i obračun plaća i priprema bilance, izrada financijskih izvješća, financijsko planiranje, kao i savjetodavne usluge.

Glavna prednost koju tvrtke očekuju ukoliko se odluče na primjenu outsourcinga najvećim je dijelom smanjenje troškova, ali sve dok je trošak glavni faktor u odluci primjene outsourcinga, ne ostvaruje se prava bit outsourcinga (Anadachee, 2012). Outsourcing računovodstvenih poslova, koji je ujedno i bit ovoga rada, znatno je manje razvijen u odnosu na IT outsourcing. Prethodno navedeno može se zaključiti sudeći prema opsegu, dubini i općenito provedbi dosadašnjih istraživanja u segmentu outsourcinga računovodstvene djelatnosti, u odnosu prema IT outsourcingu (Hayes, 1999).

Nadalje, unatoč sve većoj važnosti outsourcinga računovodstva, a s obzirom na činjenicu da je to posao koji ima puno pravnih i etičkih ograničenja, mali je broj znanstvenih radova koji proučava ovu temu. U anketi kojoj je cilj bio istražiti postojanje literature na temu outsourcinga, autora Beaumont i Khan iz 2005. godine, istraživalo se 286 radova objavljenih između 1986. godine i 2003. godine. Iako je trend primjene outsourcinga rezultirao povećanjem broja objavljenih radova, poražavajuća je činjenica kako samo jedan rad od istraživanih 286 ima primjenu u računovodstvu ( $r a d$ autora Antonucci i Lordi, 1998); pet radova u području financija i osiguranja, dok se 69 radova odnosi na informacijske tehnologije. To pokazuje veliki jaz između literature u outsourcingu računovodstva i IT outsourcingu i samo potvrđuje već istaknutu činjenicu kako je IT outsourcing napredniji od računovodstvenog. Autori Everaert, Sarens i Rommel provedenim istraživanjem iz 2010. godine pokazuju da je pri odluci primjene outsourcin$g a$ vjerojatnije da će se ono primjenjivati u provedbi manje učestalih računovodstvenih zadataka, dok je manje vjerojatno da će se outsourcing primjenjivati kod manje rutinskih i specifičnih računovodstvenih aktivnosti (Anadachee, 2012). Kamyabi i Devi (2011) svojim istraživanjem potvrđuju prethodno dobivene rezultate autora Everaert, Sarens i Rommel iz 2010. godine, ali tvrde kako dva dodatna faktora mogu utjecati na outsourcing u malim i srednjim poduzećima, a to su povjerenje u eksternog računovođu i korporativna strategija. U studiji malezijskih malih i srednjih poduzeća, Jayabalan et al. (2009) utvrdili su kako je oko 70\% ispitanih malih i srednjih poduzeća uspjelo uspostaviti i primijeniti barem nekakav oblik outsourcinga računovodstvene funkcije. Međutim, razina zadovoljstva iskustvom primjene outsourcinga računovodstvenih poslova kod malih i srednjih poduzeća, još uvijek nije na najvišoj, već najvećim djelom na srednjoj razini. Prema autorima, outsourcing računovodstvenih funkcija dobar je izbor za mala i srednja poduzeća zbog mogućnosti ispunjavanja cilja održavanja konkurentske prednosti u poslovnom svijetu. Računovodstvene funkcije igraju važnu ulogu u današnjem poslovanju. Kao rezultat toga, mala i srednja poduzeća trebaju biti svjesna svih koristi računovodstvenih informacija zbog mogućnosti bolje kontrole upravljanja i donošenja odluka kako bi mogli pristupiti novim tržištima i povećati svoju dobit u korporativnom svijetu (Jayabalan et al., 2009).

Outsourcing općenito, kao i outsourcing računovodstvene djelatnosti, rastući je fenomen u posljednjih nekoliko desetljeća, i nužno je posvetiti se istom kako bi se upoznalo s problemima s kojima se suočavaju računovodstvena poduzeća prilikom korištenja ili namjere korištenja outsourcinga. Računovodstvena se poduzeća čvrsto oslanjaju na znanje pojedinaca računovođa za svoj rad. Prilikom outsourcinga, za provedbu vlastitog posla, računovodstveno se poduzeće mora osloniti na znanje pojedinaca računovođa u vanjskom - outsourcing poduzeću. Kako bi odnos između računovodstvenog poduzeća i outsourcing poduzeća bio učinkovit, treba biti utemeljen na partnerskom odnosu tih poduzeća (Anadachee, 2012). Prema navedenom autoru, glavni pokretač outsourcinga jest smanjenje troškova, a fokus outsourcinga računovodstva jest smanjenje posebno neizravnih troškova. Eksterni outsourcing se provodi prvenstveno na taktičkoj razini kako bi se smanjili troškovi viška zaposlenika, a interni se obavlja na strateškoj razini s ciljem približavanja klijentu. Poput svih financijskih, tako se i računovodstvene djelatnosti neprestano suočavaju sa mnoštvom različitih regulativa i propisa. Računovodstvo je visoko regulirana profesija, ali i jedno od rijetkih zanimanja koja imaju utjecaj na javni interes, to jest rad i usluge računovođa korištene su od strane raznih interesnih skupina. Anadachee (2012) u svom istraživanju također dolazi do zaključka kako je outsourcing kao strategija vrlo istaknuta i korištena u informacijskim tehnologijama, ali u financijskim djelatnostima, pogotovo u računovodstvu, još uvijek je u ranoj fazi.

Slijedom prethodno navedenog, moguće je zaključiti kako je računovodstveni posao iznimno kompleksan i zahtjevan, 
a ukoliko se poduzeće primarno ne bavi računovodstvom i ne posjeduje kadar dorastao poslu računovođe, lako dolazi do problema prilikom objedinjavanja svih mogućih poslova koji se zahtijevaju od njega. Upravo u tom segmentu, poduzeća koja nude usluge outsourcinga računovodstva, pronašla su svoje mjesto i navedenu slabost poduzeća uočavaju i ističu kao svoju glavnu prednost.

Pregledom web stranica raznih poduzeća koja pružaju uslugu outsourcinga računovodstva u RH, lako se zaključuje kako navedena poduzeća pružaju kompletno sve računovodstvene usluge, od izrade mjesečnih, kvartalnih i godišnjih izvješća, usklađivanja zakonskih izvješća i internih izvješća tvrtke, zatim prikupljanja i dostave knjigovodstvene dokumentacije (godišnji i periodični statistički izvještaji, PDV obrasci i sl.), kao i predaje iste ustanovama poput Porezne uprave, HZZO-a, Mirovinskog fonda, poslovnih banaka itd. Također, temeljem naprednih alata za kreiranje izvještaja, outsourcing poduzeća pružaju detaljan uvid u poslovanje, a sve navedeno obavljaju u skladu sa zakonima i propisima, računovodstvenim, kao i standardima financijskog izvještavanja te računovodstvenim politikama.

Mala je vjerojatnost da poduzeće koje se primarno ne bavi računovodstvom, odnosno kojemu računovodstvo nije core business neće makar razmisliti o angažiranju tvrtke koja će sav računovodstveni posao obavljati za njega, posebno jer je svaki poduzetnik svjestan važnosti računovodstva i što ono predstavlja za njega. Primjenjivo na svako poduzeće - bez točnih pokazatelja o poslovanju, brzo dostupnih i provjerenih podataka nemoguće je donositi prave odluke, bez dobro vođene porezne politike poduzeće ne zna je li platilo previše poreza ili je moglo koristiti odbitak pretporeza, bez kvalitetnih izvještaja i točnih podataka, primjerice stanja zaliha, odjel nabave neće biti u mogućnosti pravilno planirati. Ukratko, bez računovodstva u poslovanju - poduzeće ne zna što radi.

\section{OUTSOURCING RAČUNOVODSTVENE DJELATNOSTI - RAZLOZI ZA I PROTIV}

U današnjem visoko konkurentnom poslovnom okruženju, postalo je neophodno da svako poduzeće bude bolje od svojih konkurenata, odnosno da iste nadmaši u poslovanju. U skladu s tim, nužno je da poduzeće u svojoj poslovnoj strategiji ostvaruje prednosti iste. Za outsourcing općenito, kao najvažnije prednosti Galetić (2011) navodi: mogućnost fokusa poduzeća na ono što radi najbolje - ono u čemu je konkurentno, uz prijenos drugih aktivnosti na dobavljača; sveukupno smanjenje troškova poslovanja; jednostavnost upravljanja cjelokupnim poduzećem; podjela rizika poslovanja s dobavljačem; jednostavnije i jeftinije pristupanje znanju, novim tehnologijama, tržištima i poslovnim prilikama itd. S druge strane, kao nedostatke outsourcinga Galetić (2011) ističe: upitna kvaliteta dobavljača; potencijalno gubljenje kontrole i ovisnost o dobavljaču; gubljenje uvida u poslovne procese; problem pri poništavanju ugovora i promjene dobavljača; korupcija u siromašnim zemljama u kojima se najčešće eksternaliziraju aktivnosti zbog jeftinije radne snage; težak nadzor ispunjavanja ugovora; dugačak proces dogovaranja.

Kao prednosti outsourcinga računovodstva, odnosno primjene vanjskog računovodstva pred vlastitim, ističu se stručnost, fleksibilnost, tajnost, sigurnost, dostupnost, točnost i racionalizacija. Ukoliko poduzeće odluči angažirati outsourcing poduzeće, ne mora više brinuti o bolovanjima, godišnjim odmorima, o dijelovima poslovanja za koje ono nije stručnjak, o zakonskim okvirima, o dostupnosti informacija čim se za istom pojavi potreba, o optimalnom korištenju resursa. Zagovornici outsourcinga prije svega naglašavaju njegovu najveću prednost u smanjenju troškova tvrtke za sporedne, odnosno non core aktivnosti. Daleko su niži troškovi ukoliko se koriste eksterne usluge čišćenja, IT usluga, nabave, računovodstva, i sl., nego da poduzeća imaju svoje zaposlenike jer na taj način ne izdvajaju novac za plaće, obrazovanje, održavanje i nabavu potrebne infrastrukture (Buneta, 2009). Umjesto zapošljavanja stalno zaposlenih i davanja istima plaće i bonuse, poduzećima se nudi zapošljavanje outsourcing poduzeća i plaćanje konkretno onoga što je poduzeću zaista potrebno i neophodno. Nadalje, outsourcing poduzeća zapošljavaju visoko kvalificirane računovodstvene stručnjake koji posjeduju znanje i iskustvo potrebno za učinkovitu obradu svih vrsta računovodstvenih poslova. Ovi stručnjaci su konstantno u toku sa stalnim izmjenama računovodstvenih pravila i propisa. Također, očekuje se od poduzeća koje obavlja outsourcing korištenje najnovije tehnologije pomoću kojih bi se računovodstveni poslovi mogli izvršiti točnije, uz manje vremena. Osiguranje sigurnosti računovodstvenih i financijskih podataka, bez obzira na prirodu poslovanja od iznimno je velike važnosti poduzeću. Uvijek postoje određeni slučajevi zlonamjernih upotreba različitih podataka o poslovanju, za nečije osobne koristi. Mnoga mala poduzeća nemaju potreban novac za ulaganje u moderne tehnologije kako bi se spriječio nastanak takvih incidenata. No, poduzeće koje obavlja outsourcing računovodstva s druge strane opremljeno je modernom tehnologijom i sustavima koji mogu osigurati iznimno veliku razinu povjerljivosti i sigurnosti osjetljivih računovodstvenih informacija. Outsourcingom računovodstvenih poslova, poduzeće se može fokusirati na druge važne funkcije koje imaju izravan utjecaj na njegovu profitabilnost. Menadžment se daleko više može fokusirati na core business i ostvariti veći profit i rejting na tržištu, kao i bolji koeficijent povrata na uložena sredstva (ROI).

Kao jedan od najvećih nedostataka outsourcinga, primjenjivo i na računovodstvenu djelatnost, navodi se upitnost kvalitete eksternaliziranog posla ili usluge, jer bez obzira na dobro sročen ugovor s outsourcing dobavljačem i mehanizme zaštite, eksternalizirani dio poslovnog procesa u potpunosti ovisi o stručnosti i raspoloživosti stručnjaka u danom trenutku. Vrlo su česte situacije da matična poduzeća vremenom gube uvid u eksternalizirane poslovne procese, a nerijetko i informacije 
potrebne za odlučivanje. Drugi nedostatak outsourcinga jest etičke prirode. Svojevrsna pobuna protiv outsourcinga postoji jer domaća ekonomija pati od gubitka radnih mjesta. Razlog tome leži u disproporcionalnoj fleksibilnosti radne snage $\mathrm{u}$ odnosu na zahtjeve tržišta. Također, negativni aspekt outsourcinga ogleda se u činjenici da su neke zemlje siromašnije od određenih multinacionalnih kompanija, što otvara vrata korupciji državnih službenika i dužnosnika siromašnih zemalja pri sklapanju ugovora o outsourcingu. Rezultat su gotovo nehumani uvjeti rada gdje su žrtve malodobna djeca i drugi nemoćni ljudi koji rade za enormno niske nadnice (Tajland, Vijetnam). Prethodno je jedno od najvažnijih civilizacijskih i moralnih pitanja koja nadilaze pravila etičnog i moralnog businessa (Buneta, 2009).

\section{ISKUSTVA PRIMJENE OUTSOURCINGA U RH}

Razlika između hrvatske i inozemne prakse outsourcinga je neupitna. Naime, velike korporacije u inozemstvu pokušavaju eksternalizirati sve ono što nije core business. Dakle, sve osim temeljnih poslovnih procesa i nosivih kompetencija podložno je eksternalizaciji. Na tržištu RH, po pitanju outsourcinga još nije takva situacija, iako se isti u realnom sektoru koristi kao poslovna strategija već mnogo godina, a od strane Vlade RH priznat je i kao prikladna mjera za smanjenje deficita (Lutilsky et al., 2015). Dosadašnja istraživanja provedena u RH ispituju koristi li se outsourcing i u kojoj mjeri u poslovanju poduzeća $\mathrm{u} \mathrm{RH}$, kao i u kojem postotku je outsourcing zastupljen u određenim djelatnostima. Za potrebe ovoga rada, ključni su podatci i zaključci dobiveni za outsourcing računovodstva, koji je prema svim istraživanjima zastupljen u znatno manjoj mjeri, iako za njim u RH postoji potražnja.

Jedno od prvih istraživanja u RH vezano za outsourcing proveo je autor Parlov 2003. godine. Namjena istraživanja bila je povezivanje i uspostavljanje (eventualnih) utjecaja upotrebe outsourcinga i ostvarivanja poslovnih ciljeva u poduzeću. Također, cilj istraživanja bio je utvrditi koristi li se i koji su glavni razlozi upotrebe outsourcinga u velikim hrvatskim poduzećima. Istraživanje je provedeno na uzorku od 91 velikih poduzeća (s više od 250 zaposlenih). Rezultati su pokazali da $73 \%$ ispitanih poduzeća primjenjuje outsourcing (61\% za dvije ili više aktivnosti), dok unutar ostalih poduzeća koja outsourcing ne primjenjuju, 44\% nije niti uzimalo outsourcing kao način poslovanja u obzir, 28\% smatra da je najbolje obaviti sve potrebne aktivnosti interno ili su pak zabrinuti za očuvanje radnih mjesta (20\%). Što se tiče razine zadovoljstva upotrebom outsourcinga, istraživanje pokazuje kako je velika većina ispitanih tvrtki manje ili više zadovoljna istim (70\%), a vrlo mali broj njih je nezadovoljno. Upravo to se može uzeti kao prvi pokazatelj outsourcinga kao korisnog alata upravljanja. Promatrajući utjecaj na ostvarivanje ciljeva poduzeća, $68 \%$ anketiranih poduzeća smatra kako outsour- cing nema ili ima mali utjecaj na ostvarivanje ciljeva poduzeća (Parlov, 2004).

Pavić (2009) je istraživao primjenu outsourcinga informacijskih tehnologija u RH. Istraživanje je provedeno na uzorku od 32 velika hrvatska poduzeća, najviše zastupljenima u prerađivačkoj industriji. Istraživanje je pokazalo kako 71,88\% ispitanih poduzeća primjenjuje outsourcing, trenutačno ga ne primjenjuje $3,12 \%$ (ali bi ga mogli početi primjenjivati), a $25 \%$ ispitanih poduzeća ga uopće ne namjerava primjenjivati. Razlozi zbog kojih poduzeća ne primjenjuju outsourcing su prvenstveno stav kako je najbolje sve aktivnosti obavljati unutar poduzeća, strah od gubitka kontrole nad poslovnim procesom, a određeni pak dio poduzeća nije uopće niti razmišljao o mogućnosti primjene outsourcinga. Ovim istraživanjem se pokazalo kako velika hrvatska poduzeća najčešće primjenjuju outsourcing prema sljedećem poretku: transport i distribucija, informacijska tehnologija, nakon toga proizvodnja te čišćenje i održavanje objekata, marketing, zaštitarska služba, zatim skladištenje i pravni poslovi, prodaja, nabava, računovodstvo i administrativni poslovi. U najmanjoj mjeri je zastupljen outsourcing kadrovskih poslova, izrade tehničke dokumentacije - nacrta, postprodaja i kantina poduzeća. Primjena outsourcinga kod 43,48\% anketiranih poduzeća uzrokovala je pojavu negativnih efekata, dok kod ostatka (56,52 \%) anketiranih poduzeća nije bilo pojave negativnih efekata. Negativni efekti primjene outsourcinga povećani su troškovi outsourcing aktivnosti, sporije rješavanje problema uzrokovano gubitkom kontrole, pojava nepredviđenih troškova i upitnost kvalitete outsourcing aktivnosti, kao i blagi oblik pojave monopola pojedinih outsourcing poduzeća koji su postali veliki proizvođači te zahtijevaju veću cijenu. Pavić (2009) također ističe kako zbog zastarjelosti tehnologije hrvatska poduzeća ne mogu konkurirati čak niti sa svojim glavnim aktivnostima na globalnom tržištu.

Šarić (2011) pokazuje kako većina velikih poduzeća u RH primjenjuje outsourcing za manje bitne poslovne zadatke. Dakako, vrsta tih zadataka ovisi o glavnoj djelatnosti poduzeća. Prema navedenom istraživanju transport i distribucija, informatičke tehnologije i čišćenje (održavanje) aktivnosti su koje se najčešće izdvajaju. Također, Šarić (2011) naglašava kako potrebe za uslugama outsourcinga u RH rastu. Postoje objektivne prednosti i zapreke za razvoj outsourcinga tržišta u RH. Kao zapreke koje bitno utječu na razvoj outsourcing navodi: nespremnost i nezrelost domaćeg tržišta za individualne davatelje outsourcinga i nezainteresiranost velikih međunarodnih subjekata za hrvatsko tržište. Također, radnički i službenički sindikati mogu biti velika zapreka aktivnostima outsourcinga, većina ugovora u javnim službama sklapa se putem javnog natječaja (temeljenog na najnižoj cijeni kao glavnom kriteriju) uslijed čega poduzeća s dumping cijenama, ali ne i sposobnostima predstavljaju prijetnju profesionalnim outsourcing tvrtkama. Zatim, u aktivnostima u informatičkom sektoru postoje problemi oko zaštite podataka. 
Brkić (2013) je istraživao outsourcing na 26 poduzeća svih veličina u RH. Uzorak se sastojao od 11 poduzeća koja posluju samo u RH, 10 poduzeća koja posluju u Europskoj uniji i 5 poduzeća koja posluju diljem svijeta. Svojim istraživanjem Brkić (2013) je došao do sljedećih zaključaka: poduzeća u RH koriste outsourcing, najčěšce $s$ ciljem smanjenja troškova poslovanja (navedeno je zaključio i Šarić u svom istraživanju 2011. godine - u tom smislu nije došlo do promjena unatoč pristupanju RH Europskoj uniji), outsourcing se u RH koristi s ciljem bolje kvalitete proizvoda, povećanja konkurentnosti, širenja na globalno tržište, zbog nedostatka stručnih zaposlenika. Prema navedenom istraživanju, u RH se najčešće koristi IT outsourcing, zatim outsourcing ljudskih resursa, računovodstva i transporta. Većina ispitanih menadžera smatra kako je vrlo dobro upoznato s pojmom outsourcinga (pozitivna činjenica za budućnost outsourcinga u RH), veličina poduzeća utječe na primjenu outsourcinga (veća poduzeća se češće odlučuju na primjenu outsourcinga jer imaju puno više poslovnih procesa nego manja). Brkić (2013) je kao razloge nekorištenja outsourcinga naveo gubitak kontrole nad eksternaliziranom aktivnosti, nedovoljna spremnost na promjene, tradicionalan način poslovanja, vlasnici manjih poduzeća smatraju kako im još uvijek nije potreban outsourcing (ostavljajući mogućnost primjene outsourcinga u budućnosti jer su upoznati s prednostima istog).

Krnjić (2014) provodi istraživanje u 29 hrvatskih poduzeća s namjerom utvrđivanja je li se i koliko promijenila svijest i praksa outsourcinga u hrvatskim poduzećima u odnosu na prethodne godine. Od 29 ispitanih poduzeća, najveći broj (22) pripada sektoru trgovine, transporta i usluga, a 7 poduzeća pripada sektoru industrije, energije i gradnje. Od ukupno 29 poduzeća, njih 14 rade diljem svijeta, a samo 10 njih od ukupnog broja radi isključivo na području RH. Rezultati pokazuju da većina ispitanih hrvatskih poduzeća primjenjuje outsourcing, a menadžeri tih poduzeća outsourcing uzimaju u obzir kao učinkovit način poslovanja. Također, rezultati su pokazali kako će tvrtke koje primjenjuju outsourcing i dalje koristiti usluge vanjskih partnera, a takav rezultat može upućivati na zadovoljstvo hrvatskih poduzeća s učincima outsourcinga. Rezultati istraživanja svakako pokazuju da se razvija svijest o outsourcingu, da su hrvatska poduzeća upoznata s konceptom outsourcinga, te da shvaćaju prednosti i nedostatke istog (Lutilsky et al., 2015).

Rezultati najnovijeg istraživanja na temu outsourcinga u $\mathrm{RH}$, provedenog od strane hrvatskih tvrtki Cronata d.o.o. i BNB Sklad d.o.o. u tekućoj 2016. godini, pod nazivom Outsourcing u službi razvoja poslovanja poduzeća u Republici $\mathrm{Hr}$ vatskoj pokazali su kako hrvatska poduzeća sve više prepoznaju prednosti outsourcinga, a najčešće koriste vanjske usluge čišćenja i održavanja $(61,7 \%)$ te informatike $(48,3 \%)$. Vanjsku zaštitu koristi $40 \%$ poduzeća, knjigovodstvene usluge njih $38,3 \%$, a usluge marketinških i agencija za odnose s javnošću $18,3 \%$. Najmanje se pak naručuju stručne usluge poduzeća za outsourcing nabave $(8,3 \%)$, prodaje $(6,7 \%)$ i administrativ- nih poslova (5\%). U RH ne postoje specijalizirana poduzeća za čitav niz usluga. Najvećom prednošću outsourcinga $45 \%$ anketiranih smatra mogućnost fokusiranja na osnovnu djelatnost, a 30\% najviše cijeni stručnost ljudi iz tvrtki koje se bave outsourcingom. Za 15\% ispitanika najvažnije je što se narudžbom vanjskih usluga smanjuju kadrovski problemi, a $10 \%$ za outsourcing se odlučuje radi ušteda. Istraživanje je provedeno na uzorku od 60 poduzeća sa 6-50 zaposlenih ili više od 250 zaposlenih, većinom privatnih, 91\% ispitanika je istaknulo kako smatra outsourcing poželjnim, a kao najveću prednost navode fokusiranje na osnovnu djelatnost. Istraživanje ukazuje na razvoj tržišta, kao i prihvaćanje svjetskih trendova. Outsourcing je važan kako bi se poduzeće maksimalno posvetilo temeljnoj djelatnosti, i zato treba znati koji se još poslovi mogu prepustiti stručnjacima iz za to specijaliziranih poduzeća. Dakle, kao svojevrsni moto outsourcinga moglo bi se reći kako poslovanje koje nije prioritetno poduzeću, a štedi i vrijeme i novac, treba prepustiti drugoj tvrtki. U RH se veći outsourcing trenutno manje zastupljenih usluga i djelatnosti tek očekuje, a da je moguć potvrđuje prethodno navedeno istraživanje jer čak 55\% hrvatskih poduzeća namjerava više koristiti outsourcing. Anketirani su djelatnici, većinom iz uprava poduzeća naveli kao ključne razloge koji ih sprječavaju u angažiranju poduzeća za outsourcing: manjak vremena i volje za traženje odgovarajućega poslovnog suradnika za outsourcing, te slab izbor poduzeća koje nude željenu uslugu. Zadnje upućuje kako poduzeća u RH zapravo jako slabo poznaju što se sve od usluga za outsourcing i koliko kvalitetno danas nudi, al istovremeno i potvrđuje kako je outsourcing nedovoljno razvijen i primjenjen u RH velikim dijelom zbog nedovoljno saznanja o istome. Kako o outsourcingu općenito, tako i o outsourcingu računovodstvene djelatnosti. No, svi rezultati dosadašnjih istraživanja od iznimne su važnosti za daljnji razvoj koncepta outsourcinga u RH. Sva istraživanja pokazuju kako domaće tvrtke usvajaju i teže uvođenju novih, suvremenih načina poslovanja. S obzirom da je među tvrtkama u razvijenim zemljama outsourcing prisutan već nekoliko desetljeća, po svemu sudeći i hrvatske tvrtke se prilagođavaju svjetskim trendovima.

\section{ZAKLJUČAK}

Sudeći po trenutnoj razvijenosti outsourcinga u RH, a posebice nakon pristupanja RH Europskoj uniji, neupitno je kako je outsourcing sve aktualniji i prisutniji i kako će se u RH u budućnosti sve više poduzeća koristiti istim, a u narednim će se pak godinama postojeće razlike koje u tom smislu postoje između RH i zemalja Europske unije izgubiti. Za outsourcing se može reći kako je on svjetski trend, stoga ne čudi što i u RH postaje sve privlačniji oblik poslovanja. Uz tu činjenicu, poduzeća se u poslovanju, ukoliko počnu s primjenom outsourcinga mogu više posvetiti i koncentrirati na sve ono što ih čini boljim od ostalih, a jasno je kako je upravo to cilj i težnja svakog poduzeća. 
Što se tiče pak razvijenosti outsourcinga računovodstvene djelatnosti u RH, ono je još uvijek manje zastupljeno nego ostali oblici outsourcinga, nedovoljno istraženo i taj "svjetski" trend još uvijek nije zaživio u RH u pravom smislu riječi, kao što je u svijetu. Sva istraživanja koje su provedena u RH, svakako su iznimno važna jer pokazuju u kojoj mjeri i u kojim djelatnostima je outsourcing zastupljen najviše, a gdje se još otvara mogućnost za razvoj istog. Definitivno tu svoje mjesto pronalazi outsourcing računovodstvene djelatnosti. U svakom slučaju, trenutna je situacija znatno pozitivnija s obzirom da se temeljem provedenih istraživanja može zaključiti kako se primjena outsourcinga računovodstva iz godine u godine povećava. Ono što se još može zaključiti jest činjenica kako većina poduzeća koja i primjenjuje outsourcing, primjenjuje u najvećoj mjeri outsourcing usluga čišćenja i održavanja, a u najvećoj mjeri outsourcing informacijskih tehnologija. U smislu namjere poduzeća za korištenje outsourcinga u budućnosti, istraživanja također pokazuju kako hrvatska poduzeća prepoznaju prednosti outsourcinga i da postoji namjera upotrebe istog. Razlozi zbog kojih poduzeća ne koriste outsourcing su: nedovoljna spremnost na promjene u tradicionalnom načinu poslovanja, strah od promjene, kao i mogućnost gubitka kontrole nad poslovnim procesima koje odluče eksternalizirati.

Situacija i istraživanja u svijetu daleko su opsežnija, pogotovo u okviru pojedinačnih doktorskih disertacija autora iz različitih zemalja (primijenjenima u radu). Upravo ta brojna strana istraživanja, koja su omogućila kompletniju sliku o poziciji outsourcinga računovodstvene djelatnosti, predstavljaju ideju i polazište budućim istraživanjima u RH, odnosno preporuku za provođenje istih. Također, potencijalno pitanje narednih istraživanja je i stupanj osviještenosti o upotrebi outsourcinga u RH - jesu li poduzeća koja primjerice koriste usluge računovodstvenih servisa svjesna kako taj način poslovanja nije ništa drugo nego sam outsourcing.

\section{LITERATURA}

Anadachee, K. (2012). Examination of outsourcing in an accounting firm: a shift in the unit analysis: ethnographic study of blocks to knowledge sharing. PhD Thesis. University of London.

Bahtijarević-Šiber, F., \& Sikavica, P. (2001). Leksikon menadžmenta. Zagreb: Masmedia.

Brkić, A. (2013). Outsourcing IT projekata u RH: diplomski rad. Split: Ekonomski fakultet u Splitu.

Buneta, A. (2009). ISO 9001 - 2008; Outsourcing: prednosti i nedostaci. Računovodstvo i financije, br. 5, 139-141. Zagreb:
Hrvatska zajednica računovođa i financijskih djelatnika.

Dražić Lutilsky, I., Dragija, M., \& Krnjić A. (2015). Influence of outsourcing on the cost management. U: Zbornik radova 4. međunarodnog znanstvenog simpozija Gospodarstvo istočne Hrvatske - vizija i razvoj. Osijek, 21-23.05.2015., str. 281294. Osijek: Ekonomski fakultet u Osijeku.

Drljača, M. (2010). Outsourcing kao poslovna strategija. U: Zbornik radova 11. Međunarodnog simpozija o kvaliteti. Kvaliteta, konkurentnost i održivost, Sv. Martin na Muri, 18.19.3.2010., str. 53-64. Zagreb: Hrvatsko društvo menadžera kvalitete i Oskar.

Espiritu, R.T., Jr. (2008). Measures of alliance success: a study of outsourcing professionals in the United States. PhD Thesis. University of Phoenix.

Galetić, L. (2011). Organizacija velikih poduzeća. Zagreb: Sinergija.

Hayes, N. (1999). Outsourcing of typical accounting functions: impact on the accounting services industry. Master thesis. Victoria University of Technology, Australia.

Jayabalan, J., Raman, M., Dorasamy, M., \& Ching, N. K. C. (2009). Outsourcing of accounting functions amongst SME companies in Malaysia: An exploratory study. Accountancy Business and the Public Interest, 8(2), 96-114.

Kamyabi, Y., \& Devi, S. (2011). An Empirical Investigation of Accounting Outsourcing in Iranian SMEs: Transaction Cost Economics and Resource-Based Views. International Journal of Business and Management 6(3), 81-94.

Latinović, B. (2010). Performantnost IT outsourcinga. Zbornik radova Fakulteta poslovne informatike (naučno-stručni časopis za teoriju i praksu iz poslovne informatike i informaciono-komunikacionih tehnologija), str. 5-22. Retrieved August 21, 2016, from http://unvi.edu.ba/Files/zbornici/ ZBORNIK_FPI_1.pdf

Paliaga, M. (2004). Outsourcing u jedinicama lokalne samouprave u Hrvatskoj: Ispravni put? Računovodstvo i financije, 10, $55-58$.

Paliaga, M. (2007). Strateško planiranje i outsourcing-budućnost hrvatskih komunalnih poduzeća. Ekonomska istraživanja, 20(1), 83-99.

Parlov, I. (2004). The influence of outsourcing on achieving business goals in large Croatian companies. Management, 9(1), 47-72.

Pavić, M. (2009). Uloga outsourcinga u povećanju konkurentnosti velikih hrvatskih poduzeća na međunarodnom tržištu. Zagreb: Poslovna izvrsnost.

Šarić, M. (2012). Eksternalizacija kao model restrukturiranja poduzeća. Tranzicija, 14(29), 122-131. Retrieved August 19, 2016, from http://hrcak.srce.hr/86075. 


\section{OUTSOURCING - A RISKY WAY TO SAVE MONEY?}

\section{Abstract:}

Outsourcing is one of the management models that can help companies achieve the optimization of all factors affecting their performance. The idea behind this model is that a company should be able to focus completely on its core activities, while all other activities should be performed by specialized companies. In this respect, outsourcing represents an effective management model, however, a question arises as to possible disadvantages and risks involved. Bearing in mind that all segments of business can be outsourced, it is of key importance to determine its impact on employees and whether it will be profitable and effective in the long term. Being constantly under pressure to improve business performance, finance and accounting departments in any company, regardless of its size and activity, are obliged to deal with accounting, taxes, and related activities. A detailed review and analysis of advantages and disadvantages, as well as the consequences of outsourcing from the point of view of the ever-growing outsourcing of finance and accounting activities is carried out using comparative and descriptive methods. Having in mind the positive experiences and its level of development, there is no doubt that outsourcing has many advantages. However, the main purpose of this paper is to explore what needs to be sacrificed to obtain these benefits and identify the possible risks involved in outsourcing for both the company and its stakeholders.

\section{Keywords:}

market requirements and competitiveness, efficiency, reduction of costs, improvement of business performance, risk. 